\title{
Human $\mathrm{CD}^{+}$and $\mathrm{CD} 8^{+} \mathrm{T}$ Lymphocytes Are Both Cytotoxic to Toxoplasma gondii-Infected Cells
}

\author{
JOSE G. MONTOYA, ${ }^{1,2,3}$ KAREN E. LOWE ${ }^{4}$ CAROL CLAYBERGER, ${ }^{5}$ DEWEY MOODY, ${ }^{6}$ DUC DO ${ }^{1}$ \\ JACK S. REMINGTON, ${ }^{1,2}$ SOHEL TALIB, ${ }^{4}$ AND CARLOS S. SUBAUSTE ${ }^{1,2 *}$ \\ Department of Immunology and Infectious Diseases, Research Institute, Palo Alto Medical Foundation, Palo Alto, \\ California 94301 ${ }^{1}$; Division of Infectious Diseases, Department of Medicine, ${ }^{2}$ and Department of Cardiothoracic \\ Surgery, ${ }^{5}$ Stanford University School of Medicine, Stanford, California 94305; Veterans Affairs Palo Alto \\ Health Care System, Palo Alto, California 94304³; and Department of Molecular Biology ${ }^{4}$ \\ and Department of Infectious Diseases, ${ }^{6}$ Applied Immune Sciences, Inc.,
} Santa Clara, California 95054

Received 6 June 1995/Returned for modification 3 July 1995/Accepted 27 October 1995

\begin{abstract}
Studies to determine if Toxoplasma gondii-specific human $\mathbf{T}$ cells lyse parasite-infected cells have yielded conflicting results. Furthermore, attempts to obtain human cytotoxic $\mathrm{CD8}^{+} \mathrm{T}$ lymphocytes have been difficult because of the lack of a reproducible system for their generation. By using paraformaldehyde-fixed, $T$. gondii-infected peripheral blood mononuclear cells as antigen-presenting cells, we developed a method whereby $T$. gondii-specific T-cell lines can be reproducibly generated. Six $T$. gondii-specific T-cell lines were generated from an individual chronically infected with $T$. gondii. Cytofluorometric analysis of these lines revealed $>99 \%$ $\mathrm{CD3}^{+}, 85$ to $95 \% \mathrm{CD3}^{+} \alpha \beta$ T-cell-receptor-positive $\left(\mathrm{TCR}^{+}\right), 5$ to $9 \% \mathrm{CD3}^{+} \gamma \delta \mathrm{TCR}^{+}, 50$ to $70 \% \mathrm{CD4}^{+}$, and 20 to $40 \% \mathrm{CD8}^{+}$cells when cells were examined during the first 3 weeks of stimulation and $>99 \% \mathrm{CD3}^{+},>99 \%$ $\mathrm{CD3}^{+} \alpha \beta \mathrm{TCR}^{+},<1 \% \mathrm{CD3}^{+} \gamma \delta \mathrm{TCR}^{+}, 20$ to $40 \% \mathrm{CD4}^{+}$, and 60 to $80 \% \mathrm{CD8}^{+}$cells when cells were examined between 5 and 11 weeks. Both $\mathrm{CD4}^{+}$and $\mathrm{CD8}^{+} \mathrm{T}$ cells had remarkable cytotoxic activity against $\mathrm{T}$. gondiiinfected target cells (30 to $50 \%$ specific $\mathrm{Cr}$ release at an effector-to-target ratio of 30:1) but not against uninfected target cells $(<10 \%$ at an effector-to-target ratio of 30:1). Cytotoxic activity by the whole T-cell lines was not $T$. gondii strain specific. Whole T-cell lines were cytotoxic for target cells infected with the C56 and ME49 strains and the RH strain (which was used to infect peripheral blood mononuclear cells). $T$. gondii-

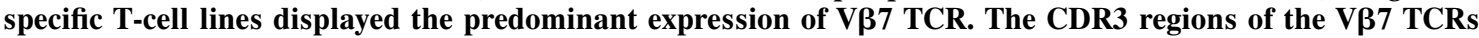
of these T-cell lines showed a striking degree of sequence identity (oligoclonality). T-cell lines obtained by the method reported here can be used to characterize functional activity of T-lymphocyte subsets in humans infected with $T$. gondii.
\end{abstract}

The major mechanism of resistance to Toxoplasma gondii in murine models of the infection has been shown to be mediated by $T$ cells $(5,25)$. The association between toxoplasmosis and conditions that affect T-cell-mediated immunity (e.g., those in patients with lymphomas or AIDS) provides indirect evidence for the role of these cells in resistance to this parasite in humans $(8,30)$. Adoptive transfer studies performed in a murine model of $T$. gondii infection indicated that $\mathrm{CD} 8^{+} \mathrm{T}$ cells were primarily responsible for resistance, although significant protection was also conferred by $\mathrm{CD}^{+} \mathrm{T}$ lymphocytes $(25)$.

It has been proposed that in addition to their production of cytokines, $\mathrm{T}$ cells may confer protection against $T$. gondii by lysis of parasite-infected cells $(6,24,32)$. Studies aimed at determining if $T$. gondii-specific human $T$ cells lyse parasiteinfected cells have yielded what appear to be conflicting results $(4,32)$. Because of the paucity of data on human $\mathrm{CD}^{+} \mathrm{T}$ cells that are cytolytic for $T$. gondii-infected target cells, we attempted to produce such cell lines to allow us to further explore the potential role of $\mathrm{CD}^{+} \mathrm{T}$ cells in humans in resistance to $T$. gondii. By using fixed $T$. gondii-infected cells as antigen-presenting cells, we developed a method whereby $T$. gondii-specific T-cell lines could be reproducibly generated. Since the T-cell receptor (TCR) is involved in T-cell activation

\footnotetext{
* Corresponding author. Mailing address: Research Institute, Palo Alto Medical Foundation, 860 Bryant St., Palo Alto, CA 94301. Phone: (415) 326-8120. Fax: (415) 329-9853.
}

and triggering of effector functions $(2,11)$, we studied the repertoires of TCR V $\beta$ expression of the $T$. gondii-specific $\mathrm{T}$-cell lines which were generated.

\section{MATERIALS AND METHODS}

Isolation of PBMC. Peripheral blood mononuclear cells (PBMC) were obtained from a healthy asymptomatic donor with serologic evidence of chronic $T$. gondii infection. T. gondii serology was performed as previously described (12, 16). The Sabin-Feldman dye test titer was $1: 128$, and the immunoglobulin $M$ enzyme-linked immunosorbent assay was negative. The donor is known to have been seropositive for $T$. gondii antibodies for more than 3 years. This study was approved by the Institutional Review Board. Signed informed consent was obtained. PBMC were isolated from heparinized venous blood by centrifugation on Ficoll-Hypaque gradients (Pharmacia LKB Biotechnology Inc., Piscataway, N.J.) as previously described (23). Cells were suspended in complete medium (CM) consisting of RPMI 1640 medium (Gibco Laboratories, Grand Island, N.Y.) supplemented with $100 \mathrm{U}$ of penicillin per $\mathrm{ml}, 100 \mu \mathrm{g}$ of streptomycin per $\mathrm{ml}$, and $10 \%$ heat-inactivated fetal bovine serum (HyClone Laboratories, Inc., Logan, Utah).

Preparation of stimulator and feeder cells. Autologous PBMC were infected with tachyzoites of the RH strain of $T$. gondii as previously described (23). Rates of infection ranged from 20 to $30 \%$. Infected cells were then fixed for $45 \mathrm{~min}$ with $1 \%$ paraformaldehyde (J. T. Baker Inc., Phillipsburg, N.J.) in phosphate-buffered saline and then washed extensively prior to addition to responder cells. Paraformaldehyde-fixed infected PBMC were used as stimulator cells. Autologous, uninfected, $\gamma$-irradiated (3,000 R) PBMC were used as feeder cells.

Generation of T-cell lines. To generate $T$. gondii-specific T-cell lines, freshly isolated PBMC were cultured in 24-well plates (Flow Laboratories, McLean, Va.) at a concentration of $2.5 \times 10^{6}$ cells per $\mathrm{ml}$ in CM and stimulated weekly with $2.5 \times 10^{5}$ stimulator cells per $\mathrm{ml}$ and $5 \times 10^{5} \gamma$-irradiated feeder cells per ml. Recombinant interleukin 2 (a gift from Chiron Corporation, Emeryville, Calif.) at a concentration of $30 \mathrm{IU} / \mathrm{ml}$ was added after 14 days of in vitro stimulation. Thereafter, recombinant interleukin 2 was added to the cell lines 
every 3 to 4 days. In addition, T-cell lines were generated by stimulation with autologous feeder cells, phytohemagglutinin (PHA) P $(2 \mu \mathrm{g} / \mathrm{ml})$ (Sigma Chemical Co., St. Louis, Mo.), and recombinant interleukin $2(30 \mathrm{IU} / \mathrm{ml})$ and used as controls.

$\mathrm{CD}^{+}$and $\mathrm{CD}^{+} \mathrm{T}$ cells were purified from the $\mathrm{T}$-cell lines by depletion of $\mathrm{CD}^{+}$or $\mathrm{CD}^{+}{ }^{+}$cells with MicroCELLector flasks (Applied Immune Sciences, Inc., Santa Clara, Calif.). The procedures followed were those recommended by the manufacturer $(7,29)$. The nonadherent cell population was recovered, and the purification process was repeated with a second MicroCELLector CD8 flask. This resulted in populations of $\mathrm{T}$ cells that were $>98 \% \mathrm{CD}^{+} \mathrm{CD}^{+}$by cytofluorometric analysis. To purify $\mathrm{CD}^{+} \mathrm{T}$ cells, MicroCELLector CD4 T-25 cell culture flasks were used. This resulted in populations of T cells that were $>99 \%$ $\mathrm{CD}^{+} \mathrm{CD}^{+}$by cytofluorometric analysis. The method used for the purification of $\mathrm{CD}^{+}$and $\mathrm{CD}^{+} \mathrm{T}$ cells was completed within 3 to $4 \mathrm{~h}$, and the cytotoxic assays were performed that same day.

Cytotoxicity assays. Target cells consisted of either autologous PHA-induced blasts obtained as previously described (23) or Daudi cells (American Type Culture Collection, Rockville, Md.). Tachyzoites of the RH, C56, and ME49 strains of $T$. gondii were obtained as previously described $(23,26)$, exposed to UV light (23), and then used to infect the PHA-induced blasts. Cytocentrifuge preparations were made from these cell preparations, and the percentage of infected cells was assessed by light microscopy (18). Rates of infection ranged from 25 to $60 \%$. Cytotoxicity assays were performed as previously described $(23,24)$.

Cytofluorometric analysis. Cells were incubated with the following monoclonal antibodies (Becton Dickinson \& Co., San Jose, Calif.): fluorescein isothiocyanate-conjugated anti-CD3, phycoerythrin (PE)-conjugated anti-CD3, PEconjugated anti-CD4, PE-conjugated anti-CD8, PE-conjugated anti-CD56, PEconjugated anti- $\gamma \delta$ TCR, and fluorescein isothiocyanate-conjugated anti- $\alpha \beta$ TCR. Propidium iodine $(0.5 \mu \mathrm{g} / \mathrm{ml})$ (Sigma Chemical Co.) was added immediately prior to analysis of the cells with a FACScan cytofluorometer (Becton Dickinson \& Co.). Background fluorescence was assessed with irrelevant isotype control monoclonal antibodies.

TCR V $\beta$ analysis. The TCR V $\beta$ repertoires of resting $T$ cells (unstimulated), $T$. gondii-stimulated T-cell lines, and T-cell lines stimulated nonspecifically with PHA were determined by the method of Choi et al. (3). Briefly, total RNA was isolated from $\geq 2 \times 10^{6}$ cells per sample with RNAzol B (acid guanidinium thiocyanate phenol) from TEL-TEST (Friendswood, Tex.) by following the manufacturer's instructions. First-strand cDNA was prepared from $4 \mu \mathrm{g}$ of total RNA in a $20-\mu$ l reaction mixture with oligo(dT) ${ }_{12-18}$ primer and Moloney murine leukemia virus $\mathrm{RNase} \mathrm{H}^{-}$reverse transcriptase according to the GIBCOBRL SuperScript protocol (Life Technologies, Gaithersburg, Md.). The cDNA was amplified with Taq DNA polymerase in a 50- $\mu$ l PCR mixture for each of the 24 known TCR V $\beta$ gene families by using a specific $5^{\prime} \mathrm{V} \beta$ sense primer and the same $3^{\prime} \mathrm{C} \beta$ antisense primer. The amplified $\mathrm{V} \beta$ products ranged in size from about 170 to $370 \mathrm{bp}$. Each PCR tube contained the $5^{\prime} \mathrm{C} \alpha$ and $3^{\prime} \mathrm{C} \alpha$ primers for a 604-bp internal-standard PCR product. Quantitation was carried out by established methods (3). For each cDNA sample, the percent V $\beta$ relative expression of each of the $24 \mathrm{~V} \beta$ gene families was calculated by the following formula:

$$
\% \operatorname{V\beta }(n)=\frac{\{[\mathrm{V} \beta(n) \text { densitometric signal }] \times 100\} /[\mathrm{C} \alpha(n) \text { densitometric signal }]}{\sum_{n=1}^{24}[\operatorname{V} \beta(n) / \mathrm{C} \alpha(n)]}
$$

Cloning and complementarity determining region 3 (CDR3) sequence analysis. PCR was performed separately with cDNA from the unstimulated (day 0 ) and $T$. gondii-stimulated (week 8 ) T cells, with only the $5^{\prime} \mathrm{V} \beta 7$ and $3^{\prime} \mathrm{C} \beta$ primers being used. The amplified VB7 products were ligated into the pCR II vector for the transformation of TA Cloning One Shot competent Escherichia coli cells (Invitrogen, San Diego, Calif.). Transformed colonies were picked at random for plasmid miniprep purification (QIAwell-8 Plus; QIAGEN, Chatsworth, Calif.) and double-stranded dideoxynucleotide sequencing. Sequences from $1 \mu \mathrm{g}$ of double-stranded plasmid DNA were amplified with T7 and SP6 promoter primers (Promega, Madison, Wis.) in 20- $\mu$ l Taq DyeDeoxy Terminator Cycle reaction mixtures (Applied Biosystems, Foster City, Calif.). PCR sequencing was performed in a Perkin-Elmer Cetus model 9600 thermal cycler with the recommended program $\left(96^{\circ} \mathrm{C}\right.$ for $15 \mathrm{~s}, 50^{\circ} \mathrm{C}$ for $5 \mathrm{~s}$, and $60^{\circ} \mathrm{C}$ for 4 min for 25 cycles with a $4^{\circ} \mathrm{C}$ hold). Samples were analyzed with an Applied Biosystems 373A DNA sequencer.

\section{RESULTS}

Following in vitro stimulation of PBMC with autologous cells infected with $T$. gondii $\mathrm{RH}$, six T-cell lines were obtained. After 5 to 11 weeks of stimulation, cells from these lines were $>99 \% \mathrm{CD}^{+},>99 \% \mathrm{CD}^{+} \alpha \beta \mathrm{TCR}^{+},<1 \% \mathrm{CD}^{+} \gamma \delta \mathrm{TCR}^{+}$, 20 to $40 \% \mathrm{CD}^{+}$, and 60 to $80 \% \mathrm{CD}^{+}$. When the cells were examined during the first 3 weeks of stimulation, cells from the

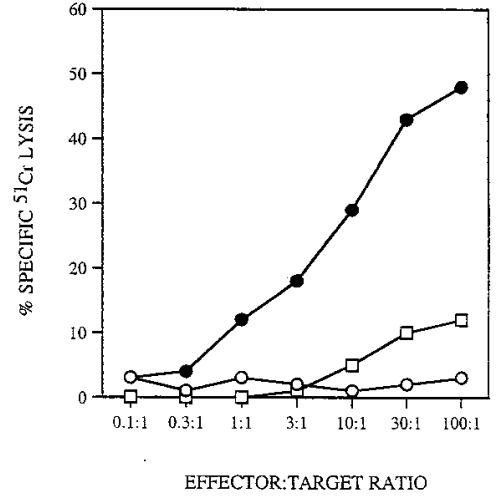

FIG. 1. Cytotoxic activity of a T-cell line against autologous PHA-induced blasts that were uninfected (open circles) and infected with $T$. gondii $\mathrm{RH}$ (solid circles) and against Daudi cells (open squares). The infection rate was 52\%.

lines were $>99 \% \mathrm{CD}^{+}, 85$ to $95 \% \mathrm{CD}^{+} \alpha \beta \mathrm{TCR}^{+}, 5$ to $9 \%$ $\mathrm{CD}^{+} \gamma \delta \mathrm{TCR}^{+}, 50$ to $70 \% \mathrm{CD}^{+}$, and 20 to $40 \% \mathrm{CD}^{+}$.

The cytotoxic activity of these $\mathrm{T}$-cell lines against uninfected, autologous, PHA-induced blasts; T. gondii-infected, autologous, PHA-induced blasts; and Daudi cells was studied from week 5 to week 11 of in vitro culture. Whereas T cells displayed minimal $(<10 \%$ specific $\mathrm{Cr}$ release at an effector-to-target ratio [ETR] of 30:1) cytotoxic activity against autologous, uninfected, PHA-induced blasts and Daudi cells, they exhibited remarkable cytotoxic activity against $T$. gondii-infected, PHAinduced blasts (30 to $50 \%$ at an ETR of 30:1) (Fig. 1). Infection of Daudi cells with $T$. gondii did not increase their susceptibility to lysis by $\mathrm{T}$ cells (data not shown). The functional activity of all the T-cell lines generated was reproducible in multiple experiments.

To determine the phenotype of the $\mathrm{T}$ cells responsible for the lytic activity against $T$. gondii-infected targets, purified populations of both $\mathrm{CD}^{+}\left(>98 \% \mathrm{CD}^{+} \mathrm{CD} 4^{+}\right)$and $\mathrm{CD} 8^{+}$ $\left(>99 \% \mathrm{CD}^{+} \mathrm{CD}^{+}\right) \mathrm{T}$ cells were obtained from five of the T-cell lines generated. Significant cytotoxic activity against autologous, T. gondii-infected, PHA-induced blasts was observed with both $\mathrm{CD}^{+}$and $\mathrm{CD}^{+} \mathrm{T}$ cells, but such activity was not observed when uninfected, autologous, PHA-induced blasts were used as targets (Fig. 2). Cytotoxicity with the $\mathrm{CD}^{+} \mathrm{T}$ cells appeared to be greater $(50 \%$ at an ETR of 30:1) than that

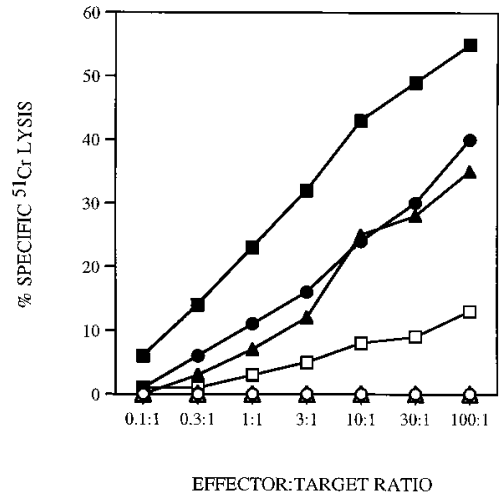

FIG. 2. Cytotoxic activity of unseparated $\mathrm{T}$ cells (circles), purified $\mathrm{CD} 4^{+} \mathrm{T}$ cells (triangles), and purified $\mathrm{CD} 8^{+} \mathrm{T}$ cells (squares) against uninfected (open symbols) and T. gondii-infected, PHA-induced blasts (solid symbols). The infection rate was $50 \%$. 


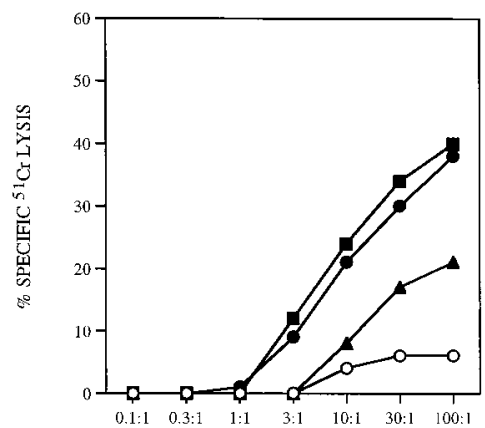

EFFECTOR:TARGET RATIO

FIG. 3. Cytotoxic activity of a T-cell line against uninfected, autologous, PHA-induced blasts (open circles) and against autologous, PHA-induced blasts infected with tachyzoites from the RH (solid circles), C56 (solid squares), and ME49 (solid triangles) strains of $T$. gondii. The infection rates were 41,35 , and $25 \%$, respectively.

with the $\mathrm{CD}^{+} \mathrm{T}$ cells $(27 \%$ at an ETR of $30: 1)$ or the unseparated T cells $(29 \%$ at an ETR of 30:1).

To determine whether the cytotoxic activity of the T-cell lines was limited to the specific strain of $T$. gondii used to infect the PBMC used as antigen-presenting cells, autologous PHAinduced blasts were infected with tachyzoites of the RH, C56, and ME49 strains and used as targets in ${ }^{51} \mathrm{Cr}$ release assays. The T-cell lines were obtained after in vitro stimulation with PBMC infected with tachyzoites of the RH strain. T cells lysed $T$. gondii-infected, PHA-induced blasts regardless the $T$. gondii strain used to infect the target cells (Fig. 3).

To characterize the effect of $T$. gondii stimulation on the TCR, we examined the TCR V $\beta$ repertoire of the T cells before and after exposure to T. gondii. The relative percent V $\beta$ expression in resting (unstimulated) $\mathrm{T}$ cells was heterogeneous, with no specific predominance or deletions of any of the $24 \mathrm{~V} \beta$ gene families (Fig. 4A). Repeated stimulation with $T$. gondii-infected, autologous PBMC resulted in a progressive increase in V $\beta 7$, which became the predominant V $\beta$ TCR family by the third week of in vitro stimulation. Figure $4 \mathrm{~B}$ shows the TCR V $\beta$ repertoire of T cells after 8 weeks of in vitro stimulation with $T$. gondii-infected, autologous PBMC. No such increase in $V \beta 7$ relative expression was observed in PHA-stimulated T cells (data not shown).

To further examine whether the predominant V $\beta 7$ gene expression was due to an oligoclonal expansion of $\mathrm{T}$ cells, the V 37 CDR3 sequences of the unstimulated and T. gondii-stim-
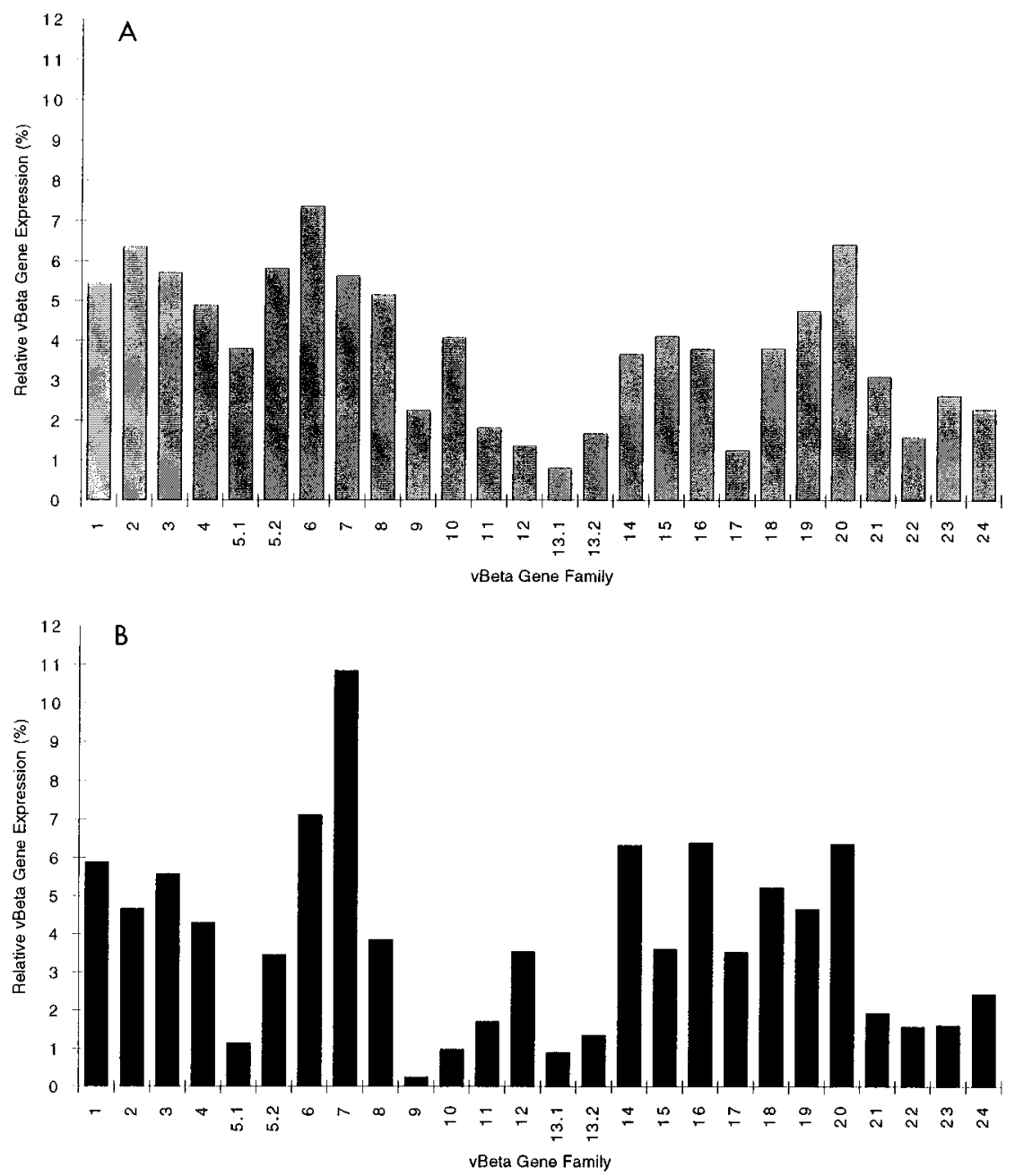

FIG. 4. Reverse transcription-PCR analysis of the TCR V $\beta$ repertoire of resting (unstimulated) T cells (A) or a T-cell line after 8 weeks of in vitro stimulation with autologous, T. gondii-infected PBMC (B). 


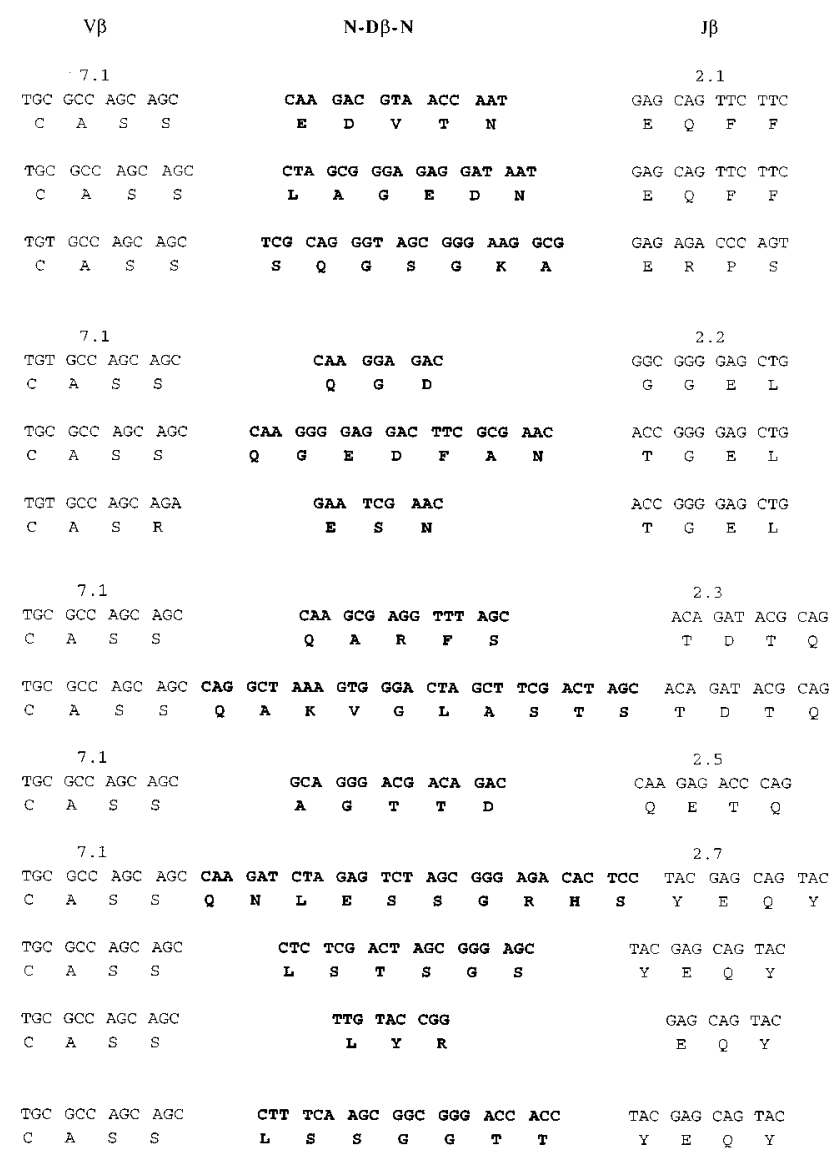

FIG. 5. V $\beta 7$ TCR CDR3 sequences of unstimulated T-cell clones.

ulated T cells were analyzed. Figure 5 shows the CDR3 (N$D \beta-N)$ region of several independently selected TCR V $\beta 7$ cDNA clones of unstimulated T cells. Each of the 13 clones has a unique CDR3 sequence. The lengths of the CDR3 range from 9 to 30 nucleotides. The expression of TCR V $\beta 7$ by these $\mathrm{T}$ cells was polyclonal on the basis of the highly diverse CDR3 sequences and lengths. Figure 6 indicates the high degree of oligoclonality observed among the TCR V 37 cDNA clones of the $T$. gondii-stimulated T cells. The same CDR3 sequence was displayed by 30 of 32 randomly selected clones.

\section{DISCUSSION}

Studies of $T$. gondii infection in animal models have demonstrated the critical role of T cells $(5,25)$ and, in particular, of $\mathrm{CD}^{+} \mathrm{T}$ cells $(25)$ in resistance to this parasite. Some of these studies performed in murine models in which $\mathrm{CD}^{+} \mathrm{T}$ cells play the major role in protection against $T$. gondii revealed that $\mathrm{CD}^{+} \mathrm{T}$ cells were cytotoxic for $T$. gondii-infected cells $(6,24)$. These observations provided impetus for studies directed at examining the in vitro functional activity of subsets of human $T$. gondii-specific $\mathrm{T}$ cells and, in particular, at determining if such $\mathrm{CD} 8^{+} \mathrm{T}$ cells are cytotoxic against $T$. gondii-infected cells.

In the present study, we demonstrate that both human $\mathrm{CD}^{+}{ }^{+}$and $\mathrm{CD}^{+} \mathrm{T}$ cells are cytotoxic against $T$. gondii-infected cells. The system of in vitro stimulation that we used to generate $T$. gondii-specific T-cell lines was chosen to mimic as closely as possible the natural process of antigen presentation for this intracellular parasite. To remove concern for the pres- ence of live organisms, which may result in the destruction of the $\mathrm{T}$ cells, infected antigen-presenting cells were fixed with paraformaldehyde. The reasons why different laboratories have obtained discrepant results in regard to the cytotoxic activity of human $T$. gondii-specific $T$ cells remain to be determined. It is likely that as was previously proposed by Curiel et al. (4), the presence of viable parasites may prevent generation of cytotoxic T-cell lines through either infection of T cells or an as-yet-undefined mechanism.

The cytotoxicity of our T-cell lines against $T$. gondii-infected cells was not specific for the strain of the parasite. These T-cell lines, which had been generated by incubation with cells infected with $T$. gondii RH, were able to lyse cells infected with the C56 and ME49 strains of the parasite. Although the lysis of target cells infected with the ME49 strain appeared to be lower than that of the RH- and C56-infected target cells, this may be explained by the lower rates of infection obtained with the ME49 strain. Lysis of target cells infected with different strains of $T$. gondii was observed despite evidence for antigenic variation among $T$. gondii strains (28). Thus, these data suggest that the three different strains that we used share a conserved epitope(s) that is recognized by $T$. gondii-specific T cells. A similar lack of strain specificity is suggested by the reports of other investigators $(4,14,15)$.

We observed that in vitro stimulation with $T$. gondii-infected PBMC affected the relative TCR V $\beta$ gene expression in T cells from a healthy donor chronically infected with $T$. gondii. The oligoclonality of the TCR V $\beta 7$ CDR3 suggests that the preferential expansion of these T cells was stimulated by TCR V $\beta 7$ recognition of a $T$. gondii antigen. Analysis of the TCR V $\beta$ repertoire and major histocompatibility complex in clinical samples from patients with $T$. gondii infection may provide further insight into the T-cell response to this parasite.

In vitro stimulation of our T-cell lines with autologous PBMC infected with tachyzoites of $T$. gondii resulted in a progressive increase over time in the percentage of $\mathrm{CD}^{+} \mathrm{T}$ cells present in our T-cell lines. It is interesting to note that this in vitro phenomenon may have an in vivo correlate, since as was mentioned above, humans with acute symptomatic $T$. gondii infection exhibit an increase in $\mathrm{CD}^{+} \mathrm{T}$ cells in their peripheral blood $(10,20)$.

Changes in the percentages of $\gamma \delta \mathrm{T}$ cells in the T-cell-line preparations were observed during the course of in vitro culture. Compared with the percentage of $\gamma \delta \mathrm{T}$ cells present in peripheral blood $\mathrm{T}$ cells from the donor $\left(1 \% \gamma \delta \mathrm{TCR}^{+}\right)$, the percentage of this subset of $\mathrm{T}$ cells from lines studied during the first 3 weeks of in vitro culture showed a remarkable increase. In this regard, we recently demonstrated that incubation of human $\mathrm{T}$ cells with cells with intracellular $T$. gondii

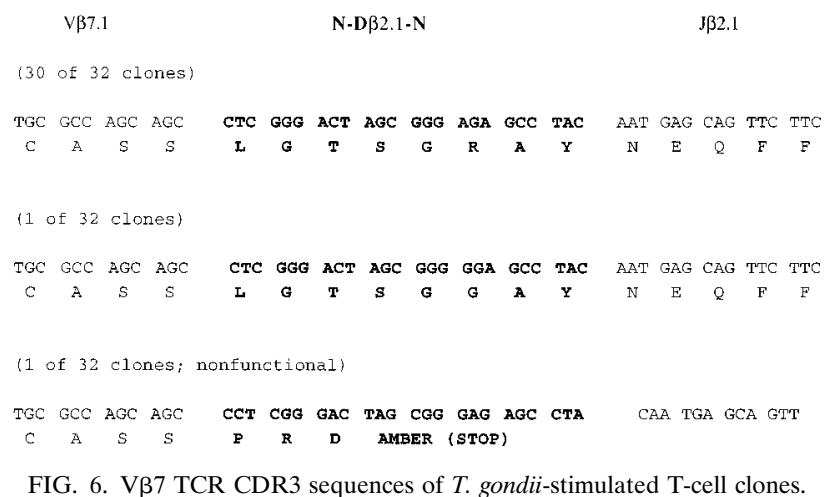


results in preferential activation and expansion of human $\gamma \delta \mathrm{T}$ cells (22). It is interesting to note that despite the initial expansion of $\gamma \delta \mathrm{T}$ cells observed in our T-cell lines following in vitro incubation with $T$. gondii-infected cells, further cycles of in vitro stimulation resulted in a decline of the $\gamma \delta$ T-cell populations. A transient increase in $\gamma \delta \mathrm{T}$ cells has also been reported to occur in the peripheral blood of patients with acute toxoplasmosis (17).

It has been proposed that lysis of $T$. gondii-infected cells may be a mechanism by which $\mathrm{T}$ cells confer protection against this organism $(6,24,32)$. Whether lysis of $T$. gondii-infected cells results in the death of the intracellular parasite remains to be determined. In studies with cells infected with Leishmania mexicana subsp. mexicana, death of the parasite did not result from the lysis of the cells by T cells (21). However, even if lysis of $T$. gondii-infected cells does not result in the killing of the intracellular parasites, release of $T$. gondii tachyzoites would expose them to activated phagocytic cells and/or anti-T. gondii antibodies and complement, which would result in the killing of the parasite by phagocytosis, complement-dependent lysis, and/or opsonization $(1,16,24)$. In addition, cytotoxic $\mathrm{T}$ lymphocytes (CTL) may exert a protective effect against $T$. gondii by the production of such cytokines as gamma interferon, which would then result in the killing or inhibition of multiplication of the parasite within macrophages (9). We cannot, however, dismiss the possibility that lysis of $T$. gondii-infected cells may be detrimental to the host. Yang et al. have proposed that lysis of $T$. gondii-infected melanoma cells by $\mathrm{CD}^{+}{ }^{+} \mathrm{T}$ cells may play a role in the pathogenesis of toxoplasmic retinochoroiditis (31).

Demonstration of the presence of human CTL against $T$. gondii-infected cells may be of relevance to the pathogenesis of toxoplasmic encephalitis in AIDS patients. It has been reported that patients infected with human immunodeficiency virus type 1 (HIV-1) develop a progressive decrease in HIV1-specific CTL activity (13) and in CTL activity against other intracellular pathogens, such as influenza and Epstein-Barr viruses (19), that are associated with the progression of HIV infection. Thus, these defects in CTL activity may lead to an increased susceptibility to opportunistic infections, increased HIV-1 replication, and the clinical transition from an asymptomatic state to AIDS (27). It remains to be determined if loss of CTL against $T$. gondii-infected cells is responsible, at least in part, for the recrudescence of latent $T$. gondii infection and the resulting development of toxoplasmic encephalitis in AIDS patients.

\section{ACKNOWLEDGMENTS}

This work was supported in part by grants AI04717 and AI30230 from the National Institutes of Health and by a MacArthur Foundation grant in molecular parasitology. C. S. Subauste is the recipient of grants from the American Foundation for AIDS Research and the University of California Universitywide AIDS Research Program.

We thank Gerard O'Donoghue and Ramila Philip for helpful discussions. We are grateful to Chiron Corp. for supplying us with recombinant interleukin 2 .

\section{REFERENCES}

1. Anderson, S. E. J., and J. S. Remington. 1974. Effect of normal and activated human macrophages on Toxoplasma gondii. J. Exp. Med. 139:1154-1174.

2. Bonifacino, J., M. Mercep, J. Sussman, R. Klausner, and J. Ashwell. 1989. The T-cell antigen receptor: a complex signal transducing molecule, p. 87104. In T. Hamaoka (ed.), Immune system and cancer. Science Society Press, Tokyo.

3. Choi, Y., B. Kotzin, L. Herron, J. Callahan, P. Marrack, and L. Kappler. 1989. Interaction of Staphylococcus aureus toxin 'superantigens' with human T cells. Proc. Natl. Acad. Sci. USA 86:8941-8945.

4. Curiel, T., E. Krug, M. Purner, P. Poignard, and R. Berens. 1993. Cloned human $\mathrm{CD}^{+}$cytotoxic $\mathrm{T}$ lymphocytes specific for Toxoplasma gondii lyse tachyzoite-infected target cells. J. Immunol. 151:2024-2031.

5. Gazzinelli, R. T., F. T. Hakim, S. Hieny, G. M. Shearer, and A. Sher. 1991. Synergistic role of $\mathrm{CD} 4^{+}$and $\mathrm{CD} 8^{+} \mathrm{T}$ lymphocytes in IFN- $\gamma$ production and protective immunity induced by an attenuated Toxoplasma gondii vaccine. J. Immunol. 146:286-292.

6. Hakim, F. T., R. T. Gazzinelli, E. Denkers, S. Hieny, G. M. Shearer, and A. Sher. 1991. CD8 ${ }^{+} \mathrm{T}$ cells from mice vaccinated against Toxoplasma gondii are cytotoxic for parasite-infected or antigen-pulsed host cells. J. Immunol. 147:2310-2316.

7. Ho, M., J. Armstrong, D. McMahon, G. Pazin, X.-L. Huang, C. Rinaldo, T. Whiteside, C. Tripoli, G. Levine, D. Moody, T. Okarma, E. Elder, P. Gupta, N. Tauxe, D. Torpey, and R. Heberman. 1993. A phase I study of adoptive transfer of autologous $\mathrm{CD}^{+} \mathrm{T}$ lymphocytes in patients with acquired immunodeficiency syndrome (AIDS)-related complex or AIDS. Blood 81:2093-2101.

8. Israelski, D. M., and J. S. Remington. 1993. Toxoplasmosis in patients with cancer. Clin. Infect. Dis. 17:S423-435.

9. Khan, I. A., K. A. Smith, and L. H. Kasper. 1990. Induction of antigenspecific human cytotoxic $\mathrm{T}$ cells by Toxoplasma gondii. J. Clin. Invest. 85: 1879-1886.

10. Luft, B. J., G. Kansas, E. G. Engleman, and J. S. Remington. 1984. Functional and quantitative alterations in $\mathrm{T}$ lymphocyte subpopulations in acute toxoplasmosis. J. Infect. Dis. 150:761-767.

11. Morley, B., K. Chin, M. Newton, and A. Weiss. 1988. The lysine residue in the membrane-spanning domain of the $\beta$ chain is necessary for cell surface expression of the T cell antigen receptor. J. Exp. Med. 168:1971-1978.

12. Naot, Y., and J. S. Remington. 1980. An enzyme-linked immunosorbent assay for detection of IgM antibodies to Toxoplasma gondii: use for diagnosis of acute acquired toxoplasmosis. J. Infect. Dis. 142:757-766.

13. Pantaleo, G., A. De Maria, S. Koenig, L. Butini, B. Moss, M. Baseler, H. Lane, and A. Fauci. 1990. CD8 ${ }^{+}$T lymphocytes of patients with AIDS maintain normal broad cytolytic function despite the loss of human immunodeficiency virus-specific cytotoxicity. Proc. Natl. Acad. Sci. USA 87:48184822

14. Purner, M., E. Krug, P. Nash, D. Cook, R. Berens, and T. Curiel. 1995. Cross-reactivity of human Toxoplasma-specific T cells: implications for development of a potential immunotherapeutic or vaccine. J. Infect. Dis. 171: 984-991.

15. Saavedra, R., and P. Herion. 1991. Human T-cell clones against Toxoplasma gondii: production of interferon- $\gamma$, interleukin-2, and strain cross-reactivity. Parasitol. Res. 77:379-385.

16. Sabin, A. B., and H. A. Feldman. 1948. Dyes as microchemical indicators of a new immunity phenomenon affecting a protozoan parasite (toxoplasma). Science 108:660-663.

17. Scalise, F., R. Gerli, G. Castellucci, F. Spinozzi, G. Fabietti, S. Crupi, L. Sensi, R. Britta, R. Vaccaro, and A. Bertotto. 1992. Lymphocytes bearing the $\gamma \delta$ T-cell receptor in acute toxoplasmosis. Immunology 76:668-670.

18. Sharma, S. D., J. R. Catterall, and J. S. Remington. 1986. Parasiticida activity of macrophages against Toxoplasma. Methods Enzymol. 132:626637.

19. Shearer, G., Z. Salahuddin, P. Markham, L. Joseph, S. Payne, P. Kriebel, D. Bernstein, W. Biddison, M. Sarngadharan, and R. Gallo. 1985. Prospective study of cytotoxic $\mathrm{T}$ lymphocyte responses to influenza and antibodies to human T lymphotropic virus-III in homosexual men. J. Clin. Invest. 76:16991704

20. Sklenar, I., T. C. Jones, S. Alkan, and P. Erb. 1986. Association of symptomatic human infection with Toxoplasma gondii with imbalance of monocytes and antigen-specific T cell subsets. J. Pediatr. 108:1-12.

21. Smith, L., M. Rodrigues, and D. Russell. 1991. The interaction between $\mathrm{CD}^{+}$cytotoxic T cells and Leishmania-infected macrophages. J. Exp. Med. 174:499-505.

22. Subauste, C. S., J. Chung, D. Do, A. Koniaris, C. Hunter, J. Montoya, S. Porcelli, and J. Remington. 1995. Preferential activation and expansion of human peripheral blood $\gamma \delta \mathrm{T}$ cells in response to Toxoplasma gondii in-vitro and their cytokine production and cytotoxic activity against $T$. gondii-infected cells. J. Clin. Invest. 96:610-619.

23. Subauste, C. S., L. Dawson, and J. S. Remington. 1992. Human lymphokineactivated killer cells are cytotoxic against cells infected with Toxoplasma gondii. J. Exp. Med. 176:1511-1519.

24. Subauste, C. S., A. H. Koniaris, and J. S. Remington. 1991. Murine CD8+ cytotoxic T lymphocytes lyse Toxoplasma gondii-infected cells. J. Immunol. 147:3955-3959.

25. Suzuki, Y., and J. S. Remington. 1988. Dual regulation of resistance against Toxoplasma gondii infection by Lyt- $2^{+}$and $\mathrm{Lyt}-1^{+}, \mathrm{L} 3 \mathrm{~T}^{+}{ }^{+} \mathrm{T}$ cells in mice. $\mathrm{J}$. Immunol. 140:3943-3946.

26. Suzuki, Y., and J. S. Remington. 1989. A method for obtaining large number of trophozoites of avirulent strains of Toxoplasma gondii using an antibody to interferon-gamma. J. Parasitol. 75:174-176.

27. Via, C., H. Morse III, and G. Shearer. 1990. HIV and the immune system. Altered immunoregulation and autoimmune aspects of HIV infection: relevant murine models. Immunol. Today 11:250-255 
28. Ware, P. L., and L. H. Kasper. 1987. Strain-specific antigens of Toxoplasma gondii. Infect. Immun. 55:778-783.

29. Whiteside, T., E. Elder, D. Moody, J. Armstrong, M. Ho, C. Rinaldo, X.-L. Huang, D. Torpey, P. Gupta, D. McMahon, T. Okarma, and R. Heberman. 1993. Generation and characterization of ex-vivo propagated autologous $\mathrm{CD}^{+}$cells used for adoptive immunotherapy of patients infected with human immunodeficiency virus. Blood 81:2085-2092.

30. Wong, S., and J. S. Remington. 1994. Toxoplasmosis in the setting of AIDS, p. 223-257. In S. Broder, T. Merigan, Jr., and D. Bolognesi (ed.), Textbook of AIDS medicine. Williams and Wilkins, Baltimore.

31. Yang, T.-H., F. Aosai, K. Norose, M. Ueda, and A. Yano. 1995. Enhanced cytotoxicity of IFN- $\gamma$ producing $\mathrm{CD}^{+}{ }^{+}$cytotoxic $\mathrm{T}$ lymphocytes specific for $T$. gondii-infected human melanoma cells. J. Immunol. 154:290-298.

32. Yano, A., F. Aosai, M. Ohta, H. Hasekura, K. Sugane, and S. Hayashi. 1989. Antigen presentation by Toxoplasma gondii-infected cells to $\mathrm{CD}^{+}$proliferative T cells and $\mathrm{CD}^{+}$cytotoxic cells. J. Parasitol. 75:411-416.

Editor: S. H. E. Kaufmann 